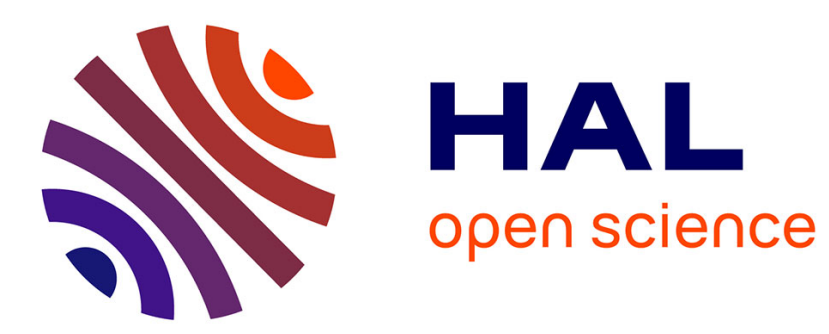

\title{
GRAIN BOUNDARY SEGREGATIONS AND HYDROGEN EMBRITTLEMENT
}

\author{
M. Aucouturier
}

\section{To cite this version:}

M. Aucouturier. GRAIN BOUNDARY SEGREGATIONS AND HYDROGEN EMBRITTLEMENT. Journal de Physique Colloques, 1982, 43 (C6), pp.C6-175-C6-186. 10.1051/jphyscol:1982617 . jpa00222298

\section{HAL Id: jpa-00222298 https://hal.science/jpa-00222298}

Submitted on 1 Jan 1982

HAL is a multi-disciplinary open access archive for the deposit and dissemination of scientific research documents, whether they are published or not. The documents may come from teaching and research institutions in France or abroad, or from public or private research centers.
L'archive ouverte pluridisciplinaire HAL, est destinée au dépôt et à la diffusion de documents scientifiques de niveau recherche, publiés ou non, émanant des établissements d'enseignement et de recherche français ou étrangers, des laboratoires publics ou privés. 
JOURNAL DE PHYSIQUE

Colloque C6, supplément au $n^{\circ} 12$, Tome 43 , décembre 1982

page $\mathrm{c6-175}$

\title{
GRAIN BOUNDARY SEGREGATIONS AND HYDROGEN EMBRITTLEMENT
}

\author{
M. Aucouturier
}

Laboratoire de Métallurgie Physique, associé au CNRS $n^{\circ} 177$, Université Paris-Sud, 91405 Orsay, France

Résumê - Les relations entre ségrégation intergranulaire et fragilisation par Thyärogène des métaux peuvent $s^{\prime}$ envisager d'un double point de vue :

$\left.1^{\circ}\right)$ L'hydrogène a une forte tendance à sêgréger dans les défauts de structure et en particulier les joints de grains. Cette ségrégation peut conditionner les propriêtés des matériaux hydrogēnēs (diffusion de l'hydrogène, fissuration induite par 1'hydrogène, propriêtês électriques dans les semi-conducteurs, etc) ét particulièrement leur comportement mécanique (fragilisation proprement dite).

$2^{\circ}$ ) L'existence de ségrégations intergranulaires d'impuretés ou d'éléments d'alliage peut modifier le comportement du matériau vis-à-vis de la fragilisation par l'hydrogène : effets synergêtiques des sēgrégations $(S, P, S b, \ldots)$ et ce 1 'hycrouẽne dans 1a fragilisation, ou au contraire, effets d'inhibicion de certaines ségrégations (carbone par exemple) sur la fragilisation intergranulaire par l'hycrogène.

Ces deux aspects sonc bien entendu liês puisque la segrêgation de 1 'hycirogène dans les joints est fonction des interäctions possibles de cet élérnent avec les autres Ėléments éventuellenent sệrégés. C'est en particulier sur ce sujet ces interactions multiples au niveau du joint et de leurs conséquences sur la tenue mécanique des alliages que les recherches ont subi un développenent ces dernières années.

L'exposé tente une synthèse des résultats et des ićées récemment publiês sur ce sujet en considérant à 1 a fois l'aspect statique (interaction, ségrēgation d'équilibre) et cynamique (transport par les dislocations, accuriulation d'hydrogène).

Abstract - The relation between grain boundary segregation and hydrogen embrittlement of metals may be discussed from two stand points :

$1^{\circ}$ ) Hydrogen has a strong tendency to segregate in siructure defects, among them, in grain boundaries. Hydrogen segregation controls the properties of hydrogenated materials in many cases (hydrogen diffusion, hydrogen induced cracking, electrical properties in semiconductors, etc) and more precisely their mechanical behaviour (embrittlement itself).

$\left.2^{\circ}\right)$ The occurence of grain boundary segregations of impurities and/or alloying elements may modify the hydrogen embrittlement behaviour of the material: synergetic effects of segregations $(S, P, S b, \ldots)$ and hydrogen on embrittlement, or, reversely, inhibiting effects of given segregations (carbon), on hydrogen induced grain boundary embrittlement.

These two aspects are obviously linked as the grain boundary segregation of hydrogen is a function of possible interaction between hydrogen and other elements. It is on this subject of multiple fold interactions in the grain boundaries and of the consequences on the mechanical behaviour of the alloys that an important emphasis has been given by the research during the past few years. 
The paper is a tentative synthesis of selected results and ideas recently published on that subject, considering both static (interactions, equilibrium segregations) and dynamic (dislocation transport, hydrogen accumulation) aspects.

\section{Introduction}

Hydrogen embrittlement of metallic materials has received a considerable interest during the past decades and a general view on the problem may be aquired by compilating the proceedings of some of the numerous Conferences devoted to it every year $(1-5)$.

This interest is justified if one considers that, among a 71 the metal-embritting impurities, hydrogen has the smallest atomic size and is one of the most commoniy available. In fact, any metallic construction has to be in contact with hydrogen during its life; moisture decomposition during metallurgical elaboration or welding, aqueous corrosion reactions, chemical products (acids, ammonia, etc.), sometimes pressurized gases, are the most common hydrogen sources. Thanks to its small atomic size, hydrogen can diffuse rapidly, even at room temperature, over Targe distances and accumulates on given microstructure defects or under the action of external stresses. Local accumulation of hydrogen may provoke a degradation of the mechanical resistance, called hydrogen embrittlement.

From the fundamental point of view, hydrogen embrittlement appears then to be largely controlled by solubility, diffusion and segregation phenomena. The role of the microstructure defects and, among them, of the grain boundaries in these phenomena is obviously a very important parameter to be encountered for in the description of the mechanism of hydrogen embrittlement.

The relation between grain-boundary segregations and hydrogen embrittlement may be considered from two stand points :

1) Hydrogen has a strong tendency to segregate in, or interact with structural defects as dislocations and internal interfaces. This tendency affects the solid solubility and the mobility of hydrogen and consequently modifies the embrittlement process.

2) Intergranular segregations of alloying elements or impurities other than hydrogen may modify the hydrogen embrittlement susceptibility of the material, as a consequence of the interaction between the segregated species and the mobile hydrogen atoms.

Those two point of view are obviously not independent and the trend of a large amount of the most recent research works on hydrogen embrittlement is to take into account the possible multiple interactions between grain boundaries, hydrogen, and other species.

This paper intend to discuss some selected recent results obtained on that subject. As no general scheme can be proposed for the moment, a tentative list of open questions will be suggested in an attempt to clarify this complex problem.

A separation must be made between the body centered cubic iron base alloys and steels, which are highly susceptible to hydrogen embrittlement, in relation with the very low solubility and very high diffusivity of hydrogen in this structure, and the face centered cubic materials (stainless steels, nickel, nickel base alloys), much less susceptible ; however, the results of recent fundamental studies on the later materials may direct a new light on some of the unexplained behaviour of the former.

11. Body centered cubic iron alloys and steels.

II. 1 Evidences and nature of hydrogen-grain boundaries interactions

The existence of an intergranular fracture shape in hydrogen embrittlement 
(see following sections) of iron alloys is the clearest envidence of the interaction between hydrogen and the grain boundaries; but intergranular fracture or cracking is the final stage of this interaction and one needs more direct and quantitative datas on the early stages of hydrogen segregation. As hydrogen is hardly detectable by the usual local or surface analysis techniques, hydrogendefects interactions are studied through macroscopic solubility and diffusion measurements. The high lattice diffusivity $\left(7.10^{-5} \mathrm{~cm}^{2} / \mathrm{sec}^{-1}\right.$ at room temperature (6)) and the small lattice solubility $\left(5.10^{-5} \mathrm{~cm}^{3} / \mathrm{cm}^{3}\right.$ at room temperature (7)) of hydrogen are strongly modified by these interaction phenomena usually denominated "trapping phenomena" (8) (9). A mathematical analysis of the permeation measurements and/or of the outgasing kinetical measurements can give an idea of the "trapping energy" $\Delta \mathrm{Hx}$ of the defects, defined as the activation energy for the lattice hydrogen/trapped hydrogen reaction equilibrium (10) (11) (12), and of the "trapping site density" NX. The results obtained for grain boundary trapping are quite scattered : $\Delta H x \simeq 24$ to $50 \mathrm{kj} /$ mole $(12)(13), \mathrm{Nx}=10^{19}$ sites $/ \mathrm{cm}^{3}$ (13).

The values must be considered as only indication values, as macroscopic measurements are impeded by many error sources arising from i) the existence of a wide range of trapping sites with different energies, which are not included in the model (11),

ii) the difficulty to

assure that the grain boundary chemistry is controled during the measurements. As seen later a very small amount of carbon or sulfur may change radically the trapping behaviour of the grain boundaries.

A direct evidence of grain-boundary hydrogen trapping can be given by the use of tritium autoradiography (13) (14) (15). Figure 1 is an example of this kind of observation. The combination of autoradiography and degasing measurements (13) (15) can give an idea of the specific trapping energy of the grain boundaries. However no quantitative answer has been given for the moment to the question of the influence of carbon or other impurities on the grain boundary trapping energy. In the recent terminology (16), "pure" grain boundaries can be described as "reversible traps", which means that their release rate is high, or their energy quite smal1. Segregated or precipitated carbon seem to increase the trapping energy, making them somewhat "irreversible" (15). The influence of other impurities, known for their segregating tendency in iron and steel, as $\mathrm{S}, \mathrm{P}, \mathrm{Sb}, \mathrm{Sn}$, is not known from this point of view.

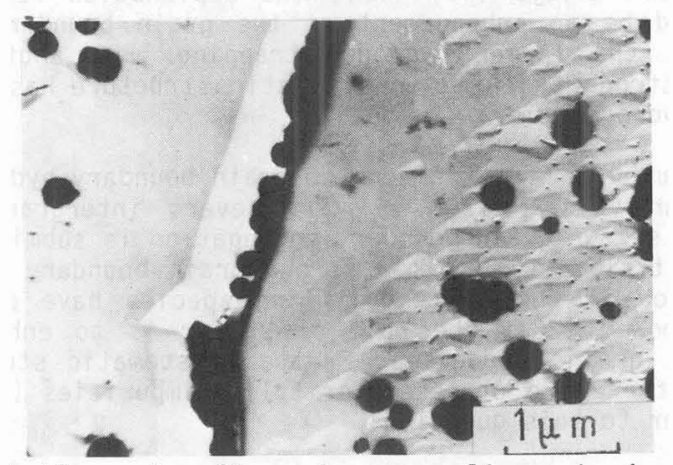

Fig.1 : High resolution autoradiography-on replica showing tritium segregation in the grain boundaries - Armco iron, cathodic charging. grain boundaries of pure iron are embrittled by hydrogen in dynamic conditions 
(mechanical testing simultaneous with hydrogen charging) provided that the testing conditions are correctly chosen (strain rate $\leqslant 5.10^{-5} \mathrm{sec}^{-1}$ ).

The mechanism of the embrittlement is evidently related to the hydrogen-grain boundaries interaction and has been proposed to be a decohesion phenomenon (19): hydrogen, transported to the regions of high triaxial stresses, reaches a critical concentration in the grain boundaries of these regions and provokes a local decohesion. The mechanism of local decohesion is still discussed (20) (21): the specific role of hydrogen on the metallic bonds in grain boundaries has not yet been explained. The influence of the strain rate on hydrogen embrittlement suggests a role of the dislocation transport, which has not been correctly quantified for the moment.

It is also established that small amounts of segregated carbon hinder the grain boundary decohesion by hydrogen (fig.2) (18) (22).

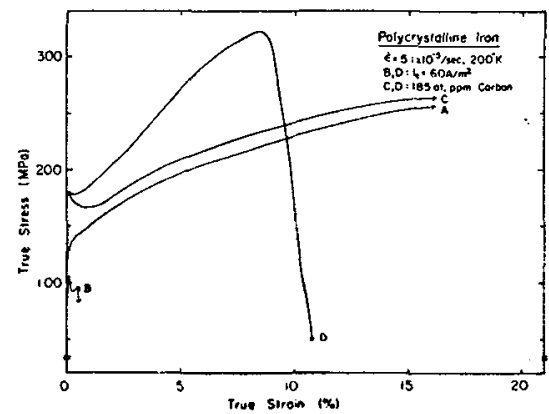

Fig.2 : From (18). Stress-strain curves of polycrystalline iron specimens : (A) pure iron without hydrogen, (B) pure iron under cathodic charging, (C) carbonized iron without hydrogen, (D) carburized hydrogen under cathodic charging (strain rate $5.1 \times 10^{-5} \mathrm{sec}^{-1}$ ).

If one considers that, as proved by tritium autoradiography, the carbon-hydrogen interactions tend to increase the hydrogen content and trapping energy of the grain boundaries in such alloys (13) (15), the explanation for the beneficial effect of carbon could be an enhancement of the grain boundary cohesion (23) (24) which compensate the larger hydrogen trapping. But another explanation could be (25) that a strong trapping in a plastic structure has in fact beneficial consequences on hydrogen embrittlement.

The role of the small amounts of sulfur on the grain boundary hydrogen embrittlement of iron is clear (fig.3) (26). A very severe intergranular decohesion appears when iron with sulfur grain boundary segregation is submitted to hydrogen charging. But as, by itself, sulfur is a strong grain boundary embrittler (23), it is difficult to know if the two embrittling species have only an additive action or if, as proposed (26), the role of sulfur is to enhance a hydrogen absorption reaction at grain boundaries. Further systematic studies, with very pure iron containing other more or less embrittling impurities ( $P, S b, S n)$ would be of interest to answer to this question. 


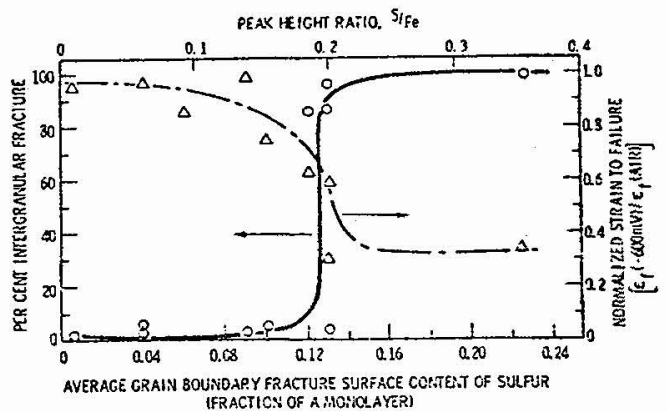

Fig.3 : From (26) Effect of the sulfur segregation on intergranular fracture of pure iron.

II.3 Hydrogen induced grain boundary fracture of BCC steels.

A very wide range of hydrogen induced fracture morphologies are observed in B.C.C. steels. The crossed influences of microstructure, mechanical properties, charging and testing conditions are quite complex. An extreme simple behaviour is observed in ultra high strengthsteels as maraging steels : the grain boundary fracture is clearly related to grain boundary trapping of large amounts of hydrogen (14) (fig.4), along with a nearly undeformable martensitic (or aged martensitic) matrix.

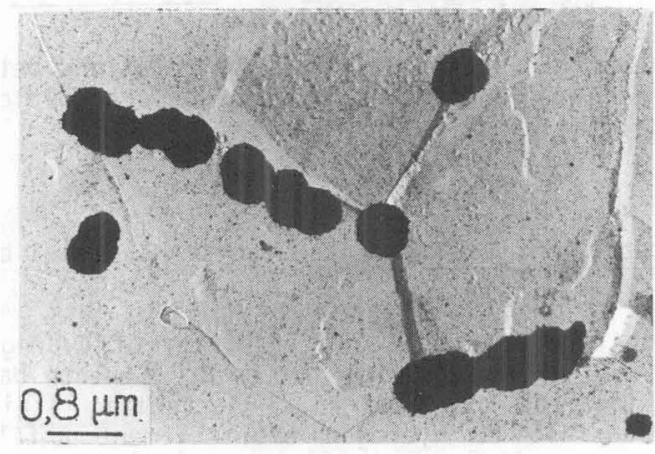

Fig.4 : High resolution autoradiography on replica showing tritium segregation and $\mathrm{H}$-induced crack initiation. Maraging steel, cathodic charging.

In quenched and tempered or low alloyed steels, the occurence of hydrogen induced grain boundary fracture seems to be related to the yield strength and/or to the segregation of impurities as $\mathrm{P}$, Sb, $\mathrm{Sn}$ ( $\mathrm{sec}$ ref. (-27) for extensive bibliography).

The concept of the critical concentration of hydrogen to produce crack propagation in a given microstructure is widely applied to describe the fracture mechanism (27) (28). Thus an interaction between hydrogen and the grain boundaries has to be accounted for in the mechanism of embrittlement but the energy or "reversibility" of such an interaction is not known and the proposed models (28) are only speculative.

The influence of other embrittling species, as $\mathrm{P}, \mathrm{Sn}, \mathrm{Sb}$, which are considered as responsible for temper embrittlement (29), on hydrogen trapping and embrittlement 
has been widely discussed during the last three years $(3,4,5)$. But, from the mechanistic point of view, it seems very difficult to propose a simple model; $\mathrm{P}, \mathrm{Sb}$ and $\mathrm{Sn}$ never segregate alone in these type of steels and multiple segregation is very often observed (24). In the most recent studies (28) (30) (31), the discussion is still open to know if the segregated metalloids (specially phosphorous) act only to decrease the critical hydrogen concentration for hydrogen-induced cracking (additive effect) (fig.5) (28) (30) or if their interaction with hydrogen enhances the embrittling power of the gas (synergetic effect) (31). Some recent autoradiography experiments done on a $\mathrm{Ni}-\mathrm{Cr}$ steel in our laboratory (unpublished results in collaboration with C.J. McMahon Jr.) suggest that segregated $\mathrm{P}$ and $\mathrm{Sb}$ do not increase much the hydrogen trapping ability of the grain boundaries.

(a) IMPURITY SEGREGATION

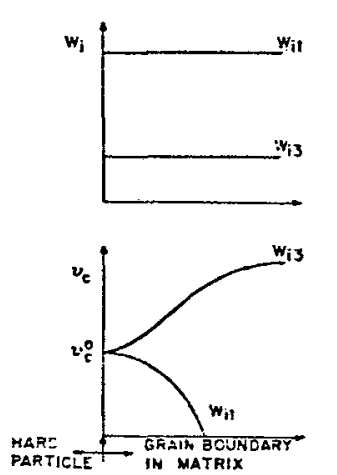

(b) IMPURITY SEGREGATION AND HYOROGEN

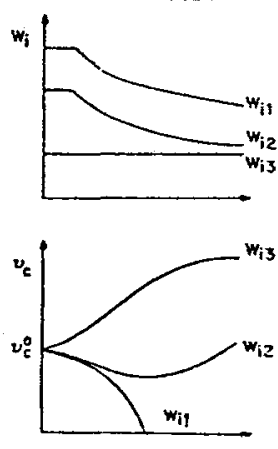

Fig.5 : From (28) Schematic representation of the relations between the variation of cohesive energy $W i$ and the early stage of crack velocity for grain boundary cracking : (a) air, (b) $\mathrm{H}_{2}$ gas.

III - Face centered cubic alloys (stainless steels and nickel base alloys).

\section{1 Hydrogen-grain boundary interaction}

The high lattice solubility and the low diffusivity of hydrogen in F.C.C. ironbase and nickel base alloys, as compared to the B.C.C. iron-base alloys, changes completely the behaviour of the materials. Austenitic stainless steels have been considered unsensible to hydrogen embrittlement until a recent period (32).

The question of hydrogen-grain boundary interaction in these alloys is a difficult one. First of all, it must be mentioned that there is no evidence of grainboundary short-circuit diffusion in austenitic stainless steels (33). This means that in absence of plastic deformation inducing dislocation accelerated transport, it is very difficult to introduce large quantities of hydrogen in those materials at room temperature. From high temperature cathodic tritium charging experiments, it has been showed that grain boundary trapping of hydrogen occurs only at the meeting points between the dislocation piling up and/or $\varepsilon$ martensite platelets and the grain boundaries (fig.6) (34) (35).

The situation is different in nickel and nickel-base alloys. Short-circuit diffusion of hydrogen along grain boundaries has been reported recently (36) (37). Apparently, this short-circuit diffusion does not depend on the grain boundary chemistry.

The trapping of hydrogen on grain boundaries of nickel or nickel-base alloys is related to the purity. Tritium autoradiography has shown a clear hydrogen 

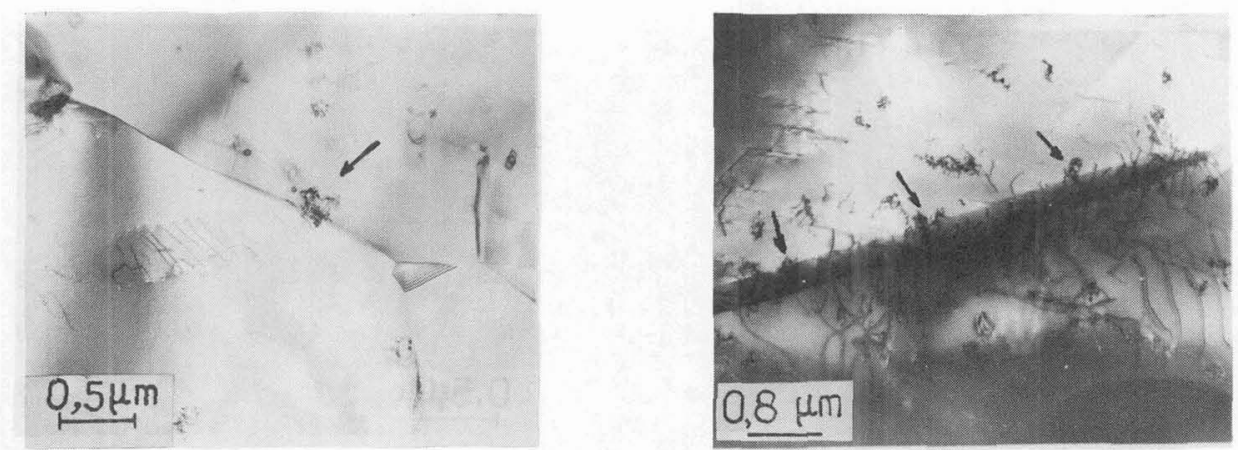

Fig. 6 : High resolution autoradiography on thin foil (observed in a $1000 \mathrm{kV}$ transmission electron microscope) showing tritium accumulation to the grain boundaries at the meeting point with a dislocation piling up or $\varepsilon$ phase nuclei. Austenitic $304 \mathrm{~L}$ steel, cathodic charging at room temperature.

trapping, only when the metal has been treated to enhance the segregation of sulfur (fig.7) (38). The trapping energy, not measured at the moment, is then strongly dependent on the grain boundary chemistry. Sulfur attracts strongly the hydrogen atoms.

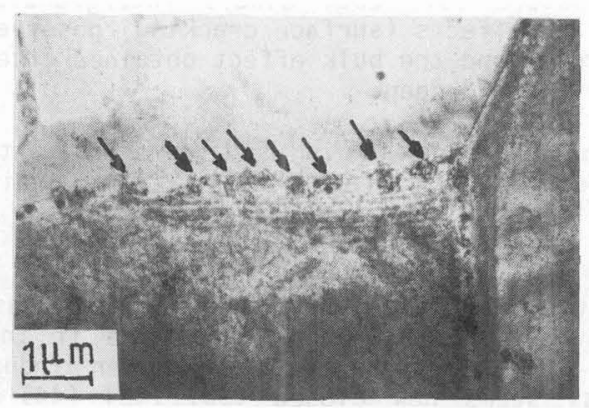

Fig.7 : High resolution autoradiography on thin foil (observed in a $1000 \mathrm{kV}$ transmission electron microscope) showing tritium trapping on grain boundaries of nickel. Nickel 270 heat treated to produce sulfur segregation; cathodic charging in tritiated salt bath $\left(150^{\circ} \mathrm{C}\right)$.

\section{III.2 Hydrogen induced cracking and fracture of austenitic stainless steels.}

The low yeld strength austenitic stainless steels are embrittled or cracked only under severe cathodic charging conditions. After room temperature cathodic charging (with recombination poison) a superficial cracking, sometimes intergranular, is induced.

The grain boundary crack initiation is due to the accelerated transport of hydrogen by the $\mathrm{H}$-induced deformation products (dislocations, $\varepsilon$ platelets) and its accumulation at the grain boundaries (fig.8) (34).

Under dynamic conditions, grain-boundary fracture is only observed in the unstable steels where a thin layer of $\alpha^{\prime}$ martensite is formed during plastic strain and/or carbide precipitation (39) (40). The mechanism is here different and not related to segregation phenomena : the $\alpha^{\prime}$ phase is responsible for the fracture, due to its high own sensitivity. 

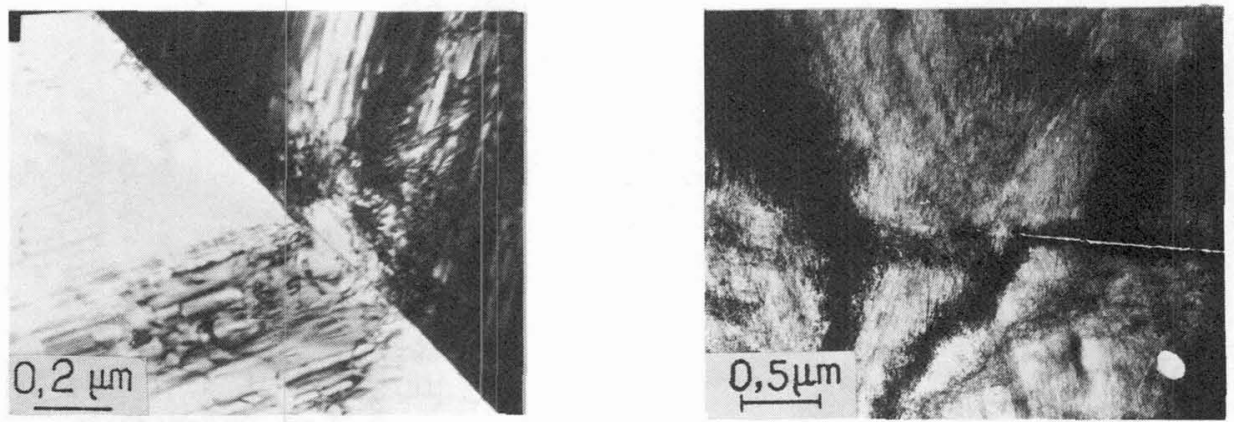

Fig.8 : Transmission electron (1000 kv) micrograph showing H-induced crack initiation, at $\varepsilon$-martensite-grain boundary meeting point. Thin foil of $304 \mathrm{~L}$ steel charged directly by cathodic polarisation at room temperature.

Thus, except perhaps for the case of a high-strength precipitation hardened stainless steel (41), the specific role of grain boundary segregation on hydrogen embrittlement of stainless steels is negligible

III.3 Hydrogen induced cracking and rupture of nickel or $\mathrm{Ni}$-base alloys.

The case of nickel and Ni-base alloys is entirely different.

The hydrogen induced fracture is, here, always intergranular. One must also separate between the surface effects (surface cracking) observed by room temperature severe cathodic charging and the bulk effect obtained after high temperature charging or under pressurized hydrogen.

The surface intergranular cracking is in fact related to the formation of a surface hydride which decomposes preferentially at the grain-boundaries (42). This behaviour is an indirect evidence of preferential grain boundary diffusion of hydrogen in nickel.

The grain boundary rupture of nickel and nickel alloys has been extensively studied. A large controversy has arisen to determine if intergranular sulfur segregation was or not necessary to produce hydrogen induced grain-boundary rupture. That controversy seems now closed (36) (43) (44) (45) (46) as pure nickel has been proved definitely to be susceptible to grain-boundary embrittlement (36) (43) (44) (Table I). Sulfur segregation plays however a major role to enhance this susceptibility (36) (43) (45) (46) (Table I) (Fig.9).

Table 1 : Effect of puricy, grain size and segregation on H-embrittlement of $\mathrm{Ni}$.So/SC in an embrittlement index (ratio of the areas under the truestress-true strain curve of non-charged and charged specimen respectively). High temperature cathodic charging.

\begin{tabular}{|c|c|c|c|}
\hline Purity and heat treatments & grain size, $\mu \mathrm{m}$ & $\mathrm{H}$ content a.ppm & So/Sc \\
\hline Ni $99.3,1050^{\circ} \mathrm{C}, 1 \mathrm{~h}+\mathrm{Q}$ & 400 & & 2.7 \\
\hline $\mathrm{Ni} 200,1200^{\circ} \mathrm{C}, 24 \mathrm{~h}+\mathrm{Q}$ & 330 & 700 & 1.6 \\
\hline $\begin{array}{l}\mathrm{Ni} 200 \text {. } 1800^{\circ} \mathrm{C}, 4 \mathrm{~h}+580^{\circ} \mathrm{C} \text {, } \\
96 \mathrm{~h} \text { (equi1. Segreg.) }\end{array}$ & 350 & & 4.5 \\
\hline $\mathrm{Ni} 270,1150^{\circ} \mathrm{C}, 4 \mathrm{~h}+\mathrm{Q}$ & 650 & & 6.5 \\
\hline $\begin{array}{l}\mathrm{Ni} 270.400^{\circ} \mathrm{C}, 2 \mathrm{~h} \\
\text { (non-equil .segreg.) }\end{array}$ & 25 & 2200 & 4.0 \\
\hline & & & \\
\hline
\end{tabular}




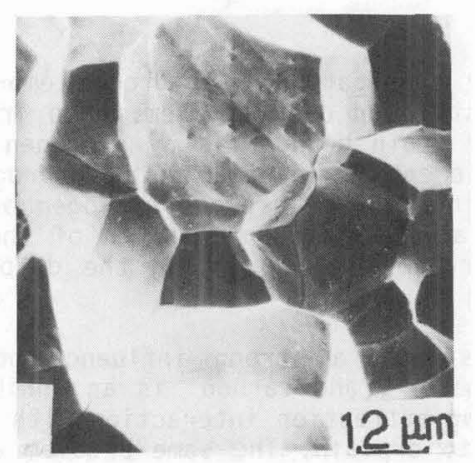

Fig. 9 : Intergranular rupture of nickel after cathodic charging at high temperature.

The mechanism of the action of hydrogen and of the combined action of hydrogen and sulfur is still under discussion. An accelerated transport by the dislocation is necessary to provoke hydrogen accumulation in the grain boundaries (43), but chemical interactions are also of great importance. For instance it could be possible that the accelerated hydrogen diffusion in the grain boundaries of nickel (the only known case of accelerated grain boundary diffusion of hydrogen in metals), has some relation with the tendency of that metal to form hydrides.

Furthermore, the specific action of sulfur (and also $S b$ and $S n$ ) on hydrogen embrittlement has been attributed to the electrochemical role of these impurities as recombination poisons $(46)$.

The nickel base alloys have basically the same behaviour as pure nickel (47) (48) (49) but, as in steels, the problem of the influence of the segregated impurities is very much complicated by the occurence of multiple interactions. For instance, C, P, Sn and Ab are reported to increase (47) (49) or decrease (48) the resistance to embrittlement.

More generally, and this could apply to all the metals and alloys mentioned in this paper, the role of hydrogen on intergranular rupture is always much more pronounced in pure materials. This means that, in industrial materials, the mulciple interaction phenomena have a general tendency to favor the reinforcement of the grain boundaries and thus to hinder the effect of hydrogen grain boundary embrittlement.

IV - The utilisation of hydrogen embrittlement to study grain-boundary segregation

The high susceptibility of some metal or alloys to hydrogen induced grain boundary rupture can be used when one needs to provoke an intergranular fracture for a research purpose. For instance, high temperature cathodic charging of nickel has been used as a tool to study, by Auger Electron Spectroscopy, the intergranular segregation of sulfur in nickel for conditions such as the sulfur segregation is not embrittling by itself $(50)(51)$.

In fact, to measure quantitatively, by A.E.S., the sulfur segregation, it is necessary that the fracture surface obtained in the spectrometer is intergranular; but this happen only for high sulfur coverage of the boundary surfaces. In order to obtain quantitative data on the kinetics of segregation, partly segregated samples have been hydrogen-charged at high temperature (cathodic charging) before introduction in the spectrometer. That procedure could be generalized to other materials where it is difficult to obtain an intergranular fracture surface. 


\section{$V$ - Conclusions}

The role of grain boundary segregation in hydrogen embrittlement of iron-base and nickel-base alloys is still an open problem. Pure iron and nickel are quite clearly embrittled at their grain boundaries by hydrogen. It is also well established that this embrittlement is caused by an hydrogen segregation effect. But, for both metals, the interaction between hydrogen and the grain boundaries does not seem to be very large and a contribution of the dislocation transport of hydrogen towards the grain boundary during the deformation is involved in the embrittlement mechanism.

Some segregating impurities have a strong influence on this phenomenon. For instance, sulfur is a promotor, and carbon is an inhibitor. As both elements are supposed to show a strong attraction interaction with hydrogen, their opposite behaviour is difficult to explain. The same problem arises for instance for the specific role of phosphorous, announced to be deleterious in steels and sometimes beneficial in nickel alloys.

It is obvious that there is a strong need of "clean" experiments on the specific action of the different segregating impurities in pure materials. The nature and significance of the interaction phenomenon between hydrogen and all the structural defects as dislocation-core, grain-boundary core, impurity atoms need to be discussed quantitatively, not only from the thermodynamical point of view (29) but also from the structural point of view (52). The exact mechanism of the rupture of metallic bonds in presence of hydrogen will then be quantified more precisely.

Another open question concerns the transport phenomena : the accelerated transport of hydrogen by dislocations is still not quantitatively interpreted ; the reason why grain boundary short-circuit of hydrogen occurs only in nickel is not explained.

The tremendous progress made on the knowledge of the grain boundary structure should now be applied to the understanding of grain boundary properties. Segregations and hydrogen embrittlement are a wide open field for that purpose.

\section{References}

(1) "Hydrogen in Metals". I.M. BERNSTEIN. A.W. THOMPSON, eds., A.S.M., Metals Park, (1974).

(2) "Hydrogen in Metals", Proc.2nd int. Cong., Chatenay-Malabry, France (1977) Pergamon Press.

(3) "Hydrogen effects in MetaIs", I.M. BERNSTEIN A.W. THOMPSON, eds. Met.Trans. of AIME (1981).

(4) "Enviromental degradation of engineering materials" Proc.2nd Int. Conf. Virginia Polytech. Inst. (1981).

(5) "Hydrogen and materials", Proc. 3rd Int. Cong. Chatenay Malabry, France, (1982) Pergamon Press.

(6) DILLARD J.. TALBOT-BESNARD S., "Hydrogen in Metals" Proc. 1st Int.Cong. Chatenay Malabry (1972) 159.

(7) GONZALES 0.D. . Trans. AIME: 245 (1969) 607.

(8) HIRTH J.P.: Met. Trans. 11a (1980) 861.

(9) BERNSTEIN I.M., THOMPSON A.W., Int. Met. Rev., 21 (1976) 3.

(10) MICAAB A., FOSTER P.K., Trans AINE 227 (1963) 618.

(11) ORIANI R.A., Acta Met, 18 (1970) 147 
(12) PRESSOUYRE G.M., BERNSTEIN I.M., Met. Trans. 9A (1978) 1571.

(13) ASAOKA T., DAGBERT C., AUCOUTURIER M., GALLAND J., Scripta Met.11 (1977) 467.

(14) AUCOUTURIER M., LAPASSET G., ASAOKA T., Metal lography 11 (1978) 5.

(15) PAES de OLIVEIRA C., AUCOUTURIER M., LACOMBE P., Corrosion 36 (1980) 53.

(16) PRESSOUYRE G.M., ref. (5) p.461.

(17) CORNET M., TALBOT-BESNARD S, in "environment sensitive fracture of Eng. Mat.", TMS-AIME (1978) 411.

(18) SHIN K.S., PARK C.G., MESHII M., ref (3) p. 209.

(19) ORIANI R.A., JOSEPHIC R.H., Acta Met. 22 (1974) 1065.

(20) TROIANO A.R., Trans. ASM, 52 (1960) 54.

(21) PRESSOUYRE G.M., ref.4, p.175.

(22) CORNET M., TALBOT-BESNARD S., in "Hydrogen in metals". Proc. 2nd J.I.M.I.S., Minakumi (1979) Japan.

(23) PICHARD C., RIEU J., GOUX C., Met. Trans 7A (1976) 181.

(24) JOLLY A., Met.Trans. 2 (1971) 341.

(25) ASAOKA T., LAPASSET G., PAES DE OLIVEIRA G., AUCOUTURIER M., LACOMBE P., ref. (2) Comm. 2B6.

(26) JONES R.H., BRUEMMER S.M., THOMAS M.T., BAER D.R., Met.Trans. 12A (1981) 1621.

(27) TAKEDA Y., MCMAHON C.J. Jr., Met.Trans. 12A (1981) 1255.

(28) KAMEDA J., JOKL M.L., Scripta Met. 16 (1982) 325.

(29) GUTTMANN M., MC LEAN D., in "Interfacial Segregations" ed. by JOHNSON W.C., BLAKELY J.M., ASM (1977).

(30) KAMEDA J., MCMAHON C.J. Jr., Met.Trans., in press.

(31) CRAIG B.D., Met.Trans. 13A (1982) 907.

(32) M.B. WHITEMAN, TROIANO A.R., Corrosion, 21 (1965) 53.

(33) TISON P., FIOELLE 3.P., Report CEA, N 2231 (1981) Paris.

(34) CHENE J., OVEJERO garcia J., PAES de OL IVE IRA C., AUCOUTURIER M., LACOMBE P., J. Mic. Spect. Elect. 4 (1979) 37.

(35) CHENE J., AUCOUTURIER M., ARNOULD-LAURENT R., TISON P., FIDELLE J.P., ref. (3), p. 583.

(36) SHEHU Y., Thesis Doct.Ing., Orsay (1981) France

(37) LATANISION R.M. in "Atomistics of encironmentally Induced Fracture", NATO Adv.Res. Inst. on atomistics of fracture, Ajaccio, France (1981).

TSURU T., LATAMISION R.M., Scripta Met. 16 (1982) 575.

(38) MENUT P., SHENU Y., CHENE J., AUCOUTURIER M., BARBIER J., SAINDRENAN G., Miami int. Symp. on Metai-H syst., Miami (Apr. 1981).

(39) CHENE J., SHEnU Y., AuCOUtuRIER M., Bull. Cercle d'et. Met. 1419 (1980) 16-1.

(40) BRIANT C.L., ref (3) p.527.

(41) AZOU P.F., FIDELLE J.P., ref (5) p.731.

(42) MENUT P., Thesis Doct.Ing., Orsay (1982) France

(43) MENUT P., SHEHU Y, CHENE J., AUCOUTURIER M., ref. (5) p.857.

(44) STULEN R.H., in "Hydrogen in Metals" Proc. 2nd J.I.M.I.S., Minakami (1979) Japan. 
(45) EASMAN J., MATSUMOTO T., NARIJA N., HEUBAUM F., BIRNBAUM H.V., ref (3) p.397.

(46) LATANISION R.M., KURKELA M., LEE. F., ref.(3) p.379.

(47) CORNET M., BERTRAND C., DA CUNHA BELO M., Met.Trans. 13A (1982) 141.

(48) WAS G.S., TISCHNER H.H., LRTANISION R.M., PELLOUX R.M., Met.Trans. 12A (1981) 1397 and 1409.

(49) FUNKENBUSCH A.W., HELDT L.A., STEIN D.F., Met.Trans. 13A, 611.

(50) LARERE A., GUTTMANN M., DUMOULIN P., ROQUES-CARMES C., Acta Met. 30 (1982) 685.

(51) BARBIER-VITART J., SAINDRENAN G., LARERE A., ROQUES-CARMES, J.Mat.Sci.17 (1982) 387.

(52) BALLUFFI R.W., in "Interfacial segregations" ed. by JOHNSON W.C., BLAKELY J.M., ASM (1977).

\section{DISCUSSION}

A. REVCOLEVSCHI : Are only "soft" $\beta$ limiting isotopes usable in your very interesting microautoradiographic technique?

M. AUCOUTURIER : The resolving power of the technique is related to the energy of the $\beta$ emission, but, as $\beta$ spectra are continuous, it is often possible, for all $\beta$ emitters, to find experimental parameters (overall activity of the specimen, exposure time, number of observed areas) to obtain a resolving power between 0.1 and $0.5 \mu \mathrm{m}$. 